\title{
Banking sector credit development and investment productivity in Nigeria
}

\author{
Ogbuagu, Uchechi Rex ${ }^{*}$, Chijioke, Mercy Ihuoma, Udah, EnangBassey \\ Department of Economics, University of Calabar, Calabar, Nigeria
}

Email address:

rexogbuagu@gmail.com(Ogbuagu, U. R.),mercyic@yahoo.com (Chijioke, M.), annangudah@unical.edu.ng (Udah, E.)

\section{To cite this article:}

Ogbuagu, Uchechi Rex, Chijioke, Mercy Ihuoma, Udah, EnangBassey. Banking Sector Credit Development and Investment Productivity in Nigeria. International Journal of Economic Behavior and Organization. Vol. 1, No. 6, 2013, pp. 61-68.

doi: 10.11648/j.ijebo.20130106.12

\begin{abstract}
In Nigeria, commercial bank credit represent almost 90 percent of the financial system assets and about twothirds of the total credit is allocated to the private sector. Financing of investments through the credit market system portends that investments are associated with a level of productivity. Thus a developed credit market that efficiently utilizes its resources will contribute optimally to economic development. One will expect that increased earnings will lead to increased availability of credits and therefore a better developed credit market but our experience is to the contrary. In contrast, it is difficult to explain the low rate of development registered in most African countries including Nigeria in comparison to the quantum of export earnings they receive. In particular, Nigeria earned enormous revenue from crude petroleum export during oil boom years yet development in Nigeria crawls. This study therefore examined the relationship between credit market development as measured by bank sector credit ratio to GDP and investment productivity, measured as ratio of GDP to Gross Domestic Investment, GDI in Nigeria using data from 1970-2010 and standard econometric method of error correction mechanism. We observed that the improvement in the banking sector reforms ranging from structural adjustment programme (SAP) to the present consolidation era has not been translated to credit market development. This is attributed to inefficient utilization of credit market funds which results in low level of per capita income, low level of investment and ultimately poorly developed banking credit market in Nigeria. Based on the findings of the study, the following policy implications can be drawn: increase in deposit rate will encourage savings, promote credit market development and increase investment. Similarly; a reduction in lending rate will encourage borrowing for capital project financing that will lead to increased investment productivity, increased output, better use of the bank credit market and hence a better developed credit market. Through this, development in the credit market can contribute significantly to economic development via investment productivity. There is the need to increase per capita income through encouraged participation in credit market investment. Thus returns on investment in the credit market should be improved. At present people prefer to spend their money on consumption goods because of the discouraging low deposit rate in the banks. Improved deposit rate will definitely improve investment productivity and economic development through the multiplier process. Foreign direct investment was found to encourage investment productivity; policy should be geared towards attracting more FDI in Nigeria.
\end{abstract}

Keywords: Banking Sector, Credit Market Development, Investment Productivity, Foreign Direct Investment, Financing

\section{Introduction}

It is accepted among economists that a well-developed credit market encourages economic development and growth. Credit market provides funds to investors at a cost equal to the lending rateand through the multiplier process; it is expected to contribute significantly to the development of the economy. Early economists like Schumpeter (1911), identified banks' role in facilitating technological innovations through intermediation role and opined that the allocation of savings through identification and funding of entrepreneurs are veritable tools for achieving the macroeconomic objectives of economic development (Oluita, 2009). This implies that financing of investments through the credit market system portends that investments are associated with levels of productivity. Thus a developed credit market thatefficiently utilizes its resources will contribute optimally to economic development. 
In Nigeria, commercial bank credit represent almost 90 percent of the financial system assets and about two-thirds of the total credit is allocated to the private sector. One will expect that increased earnings will lead to increased availability of credits and therefore a better developed credit market but our experience is to the contrary. Itis difficult to explain the low rate of development registered in most African countries including Nigeria in comparison to the quantum of export earnings they receive. In particular, Nigeria earned enormous revenue from crude petroleum export during oil boom years. Available records show that, oil revenue and public sector spending increased from $\$ 813.4 \mathrm{M}$ and $\$ 2,740.6 \mathrm{M}$ in1974 to $\$ 8,025,953.48 \mathrm{M}$ and $\$ 4,605,319.72 \mathrm{M}$ in 2012 respectively, without leading to appreciable level of economic growth and development. This may be attributed to the inability of the credit market to efficiently channel its resources to core growth activities of the private sector where investment productivity will be optimal.

Bank credit productivity can be measured with the ratio of bank deposit to Gross National Product, GDP. Comparatively, ratio of bank deposit to GDP for Nigeria, Indonesia and South Africa were 10 percent, 50 percent and 51 percent respectively in 2001. In 2002 the ratio of bank deposit to GDP in Nigeria was only one-fifth of that of Indonesia and about half of that of South Africa. While 60 percent of the credit in Nigeria was utilized by the public sector, as compared to the use of only 30 percent and 10 percent of such credits in Indonesian and South Africa respectively (David, 2003). This indicates that in Nigeria, financing of public debts remains the primary function of the credit market while private sector financing is of a secondary importance, yet economists agree that it is the private sector that drives an economy.

Over the years, various policies and strategies have been adopted by the government which had ensured continuous growth of the credit market. These strategies and policies include; the Nigerian Enterprise Promotion decree of 1972 which was amended in 1977 as Indigenization decree, the Structural Adjustment Programme of 1986, Guided Deregulation of 1994, the National Economic Empowerment Development Strategies of 1999 and the bank Consolidation of 2004 among others. Despite these efforts, economic development in Nigeria crawls. The high ratio of banking sector credit toGDP suggests that availability of finance is not the problem, rather, the inefficient and low productivity of investment in the private sector. On the contrary, the studies for Ghana, Ivory Coast and India by Osei (2005), Nzue (2006) and Mishra, Das and Pradhan (2009), where investment productivity is high, reveal that credit market development enhanced economic development in the respective economies.

This study therefore is set to examine the relationship between credit market development as measured by bank sector credit ratio to GDP and investment productivity, measured as ratio of GDP to Gross Domestic Investment, GDI in Nigeria. The paper is organized as follows. Section 2 reviews the existing literature on the link between credit market development, investment and economic development. Section 3 presents background information and stylized facts on credit market development, investment productivity and economic development in Nigeria. Section 4 sheds light on the methodology and data used for the empirical analysis.Section 5 reports the estimation results while section 6 concludes the work.

\section{Literature Survey}

There is substantial literature on the role of credit market development and investment. This literature provides support for the argument that economies with better and efficient credit systems develop faster while inefficient credit systems bear the risk of bank failure (Kasekende, 2008). Credit institutions intermediate between the surplus and deficit sectors of the economy. Thus, a better functioning credit system alleviates the external financial constraints that impede credit expansion, and the expansion of firms and industries (Mishkin, 2007). The financial intermediaries although regulated, still determine the strategies for allocating funds, thereby playing significant role in determining the type of investment activities, the level of employment generation, and distribution of income (Gross, 2001). The availability of an optimallyfunctioning credit market allows the realization of this role which is often essential and significant for the development of an economy. According to Athanasios and Anthonios (2010), credit market development is strongly correlated with development rate of real GDP per capita.

Acemoglu et al (2004) developed a theory of financial development which improves endogenously in the development process. The theory holds that; due to projectsize indivisibility, security markets in less developed countries may be incomplete. This discourages investment in profitable projects with high risk tendency, despite the fact that security markets improve as the economy reaches higher stages of development. Stock markets contribute to the mobilization of domestic savings by enhancing the set of financial instruments available for savers to diversify their portfolios. In doing so, they provide an important source of investment capital at relatively low cost. A wellfunctioning and liquid stock market helps investors to diversify away unsystematic risk, which will increase the marginal productivity of capital. Development of stock market is necessary to achieve full efficiency of capital allocation if the government is to liberalize the financial system. While banks finance only well-established safe borrowers, stock market can finance risky, productive and innovative investment projects. In terms of physical accumulation, stock markets and banks provide sources of external financing to firms and so create information that guide the allocation of resources. However, information in stock market is contained in equity prices, while information in the banking sector is collected by loan managers (Caporel et al, 2005).

Greenwood and Smith (1996) show that large stock 
markets can lower the cost of mobilizing savings and hence facilitate investment in most productive technologies. Bencivenga et al (1996) and Levine (1991) argue that stock market liquidity (the ability to trade equity easily) is more relevant to development because profitable investments require long-run commitment of capital and savers do not like to relinquish control of their savings for long periods. Thus, Kyle (1984) argues that liquid stock market can increase incentives for investors to get information about firms and improve corporate governance.

On the direction of the causal relationship between credit market development and economic development, Atje and Jovanic (1993) used cross-sectional regression method and concluded that credit market development have long-run impact on economic development. By extension, higher investment productivity should enhance the development of the credit market. Demetriades and Hussein (1996) in their study on thirteen countries observed that stock market influences development through a number of channels; liquidity, and risk diversification, acquisition of information about firms, corporate governance and saving mobilization. They concluded that the issue of causality is country specific rather than general as postulated by Oluitan(2009). Saci, Giorgioni and Holden (2009) estimated the relationship for thirty developing countries with annual data over the period 1988-2001 applying two-step GMM. They found that the variable; domestic credit by banks and other financial institutions as a percentage of GDP had significantly negative coefficients with stock market traded value over GDP. When stock market traded value over GDP is replaced by stock market turnover ratio, the effect of domestic credit by banks and other financial institutions as percentage of GDP became insignificant. However, in each case, the effect of the stock market variables on development is positive and significant.

Vazakidis and Adamopoulus (2009) investigated the relationship between credit market development and economic development for Italy over the period; 1995to 2007 using a vector error correction model (VECM). The empirical results indicated that economic development had positive effect on credit market development, while inflation rate had a negative effect within the period. Bank development was determined by the size of bank lending directed to private sector.They concluded that periods of low inflation rates lead to higher economic development rates. A study by Luintel and Khan (1999) on ten developing economies observed bidirectional causality between financial development and economic development in all samples. Osei (2005) carried out a study on Ghana Stock Exchange (GSE) and the result shows that stock market performance granger causes economic development in the economy. This result upheld the fact that economic development does not predict stock market development in Ghana. However, this was attributed to low level of income as evidenced in most developing countries. Similar result was obtained by Nzue (2006) who investigated the relationship between the development of the Ivorian stock market and the country's economic performance. His findings suggest that gross domestic product and stock market development were co-integrated when the control variables were included in the analysis. In other words, there exists a long-run relationship between these variables taken together. The result also indicates a unidirectional relationship between the capital market and the economic development of the economy. Also Mishra, Das and Pradhan (2009) studied credit market development and economic development in India using Vector Autoregressive Model (VAR) and concluded that there exists a positive relationship between both variables. This implies that credit market development will necessarily generate opportunities for investment in the economy which will attract the new class of entrepreneurs with handful of innovative ideas and this will inevitably ensure higher economic development in the long-run. Other economists like Lucas (1988) had announced skepticism about the capacity of financial systems to affect economic development. Whereas the bank based theory emphasizes the positive role of banks in the development and growth of any economy, it also stresses the shortcomings of marketbased financial systems. It is argued that banks can finance development more effectively than markets in developing economies and in the case of state owned banks, allocation of savings can be undertaken strategically to avoid market failure. Thus far, it is accepted that investment leads to economic development and credit market development will be enhanced by investment productivity. However, it is the productivity of investment that determines the efficient allocation of credit and speed of economic development.

\section{Trends in Investment Productivity and Credit Market Development in Nigeria}

Figurelbelow shows that banking sector credit declined sharply between 1970 and 1974 before the advent of oil in the economy, but with the discovery of oil, it increased significantly and lasted till 1986. The introduction of the structural adjustment programme (SAP) in 1986 had adverse effect on the banking sector credit at the initial stageas it decreased persistently till 1990. Between 1990 and 1994, banking sector credit regained momentum up to 1994 before the introduction of the guided deregulation that further worsened the development of thecredit market. Within this period, there was inconsistency in the pattern of the growth level of banking sector credit in the country, in other words, there was no remarkable impact of the policy on the banking sector credit. However, since 2006 after the bank consolidation of 2004, banking sector credit has witnessed a remarkable improvement. On the other hand, the same cannot be said of investment productivity in Nigeria. Though investment productivity increased along with banking sector credit following the discovery of oil in Nigeria, the increase was not commensurate with that of the 
banking sector credit. Since the post-SAP period, there has been persistent decline in investment productivity which is detrimental to the development of any economy.

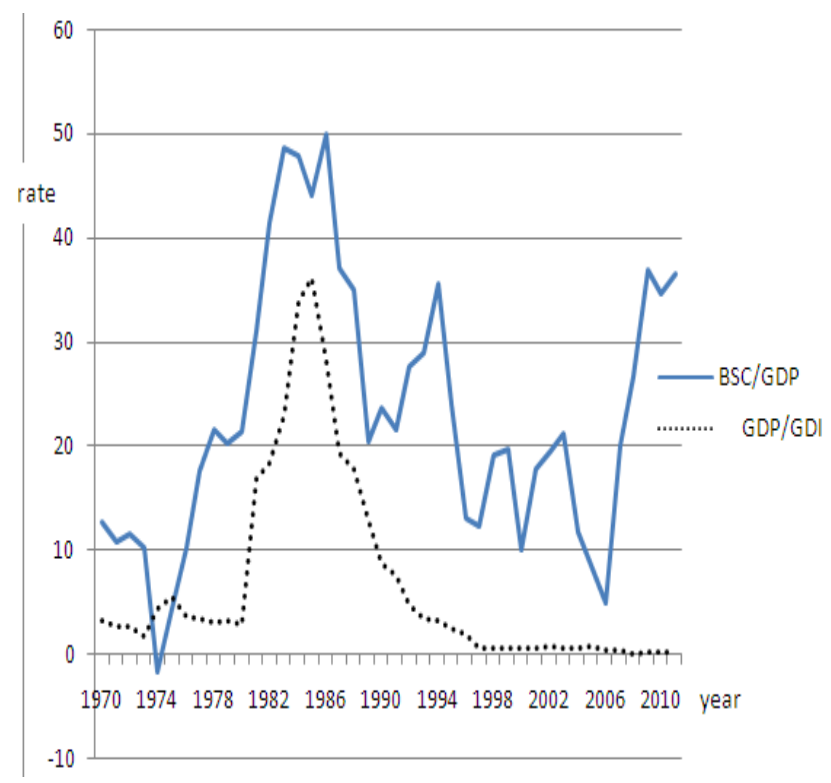

Fig 1. Banking sector credit and investment productivity in Nigeria 19702012

$$
B S C / G D P=f(G D P P C, G D P / G D I, D R, T O P, F D I)
$$

This, in the linear form can be rewritten as:

$$
B S C / G D P=a_{0}+a_{1} G D P P C+a_{2} G D P / G D I+a_{3} T O P+a_{4} I N T R S+a_{5} F D I+\varepsilon_{t}
$$

We however; adopted the semi-log model hence;

$$
\log (B S C / G D P)=a_{0}+a_{1} \log (G D P P C)+a_{2} \log (G D P / G D I)+a_{3} T O P+a_{4} I N T R S+a_{5} F D I+\varepsilon_{t}
$$

Where, $a_{1}, a_{2}, a_{3}, a_{4}$ and $a_{5}$ are the coefficients of the model estimate while $\varepsilon_{\mathrm{t}}$ is the white noise error term, anda $\mathrm{a}_{1}>0, \mathrm{a}_{2}>0, \mathrm{a}_{3}>0, \mathrm{a}_{4}<0$ and $\mathrm{a}_{5}>0$ and

$\mathrm{BSC} / \mathrm{GDP}=$ Credit to the banking Sector

GDP/GDI = Investment Productivity (Earned output per unit invested)

GDPPC $=$ Gross Domestic Product per capita.

INTRS $=$ Interest Rate Spread (Lending Rate - Deposit Rate)

TOP $=$ Trade Openness.

FDI $=$ Foreign Direct Investment

\subsection{Method of Estimation}

Standard econometric techniques are adopted in this study: unit root test, granger causality test, co-integration and error correction mechanism (ECM).

\subsubsection{Unit Root Test}

Among different methods of unit root test the Augmented Dickey Fuller (ADF) test which considers lagged values of the dependent variables in order to obtain an unbiased estimate of $\delta$, the coefficients of the lagged variable $\mathrm{Y}_{\mathrm{t}-1}$ was used. If the order of integration is $\mathrm{I}(0)$, we conclude that $Y_{t}$ has no unit root. Otherwise, we accept that $Y_{t}$ has unit root.

The ADF unit root test requires the estimation of the regression

$$
\Delta Y_{t}=a_{0}+\beta Y_{t-i}+\sum_{i=1}^{p} \delta_{i} \Delta Y_{t-i}+\varepsilon_{t}
$$

where,

$$
\begin{aligned}
& \Delta \mathrm{Y}_{\mathrm{t}}=\text { first difference of } \mathrm{Y}_{\mathrm{t}} \\
& \alpha_{0}=\text { the intercept } \\
& \delta_{\mathrm{i}}=\text { the trend coefficient } \\
& \beta=\text { the coefficient of the lagged term } \\
& \mathrm{t}=\text { the time or trend variable } \\
& \mathrm{p}=\text { the number of lagged terms } \\
& \varepsilon_{\mathrm{t}}=\text { the white noise. }
\end{aligned}
$$

The hypotheses to be tested are:

Ho: $\beta=0$, i.e., there is a unit root (the time series is nonstationary) 
H1: $\beta<0$, i.e., there is no unit root (the time series is stationary).

If the calculated ADF test statistic is higher than MacKinnon's critical values, then the null hypothesis $\left(\mathrm{H}_{0}\right)$ is accepted and the time series is considered non stationary or not integrated of order zero, i.e., I(0). Alternatively, the rejection of the null hypothesis implies stationarity of the underlying time series. Failure to reject the $\mathrm{H}_{0}$ leads to the test on the difference of the time series. In other words, differencing is conducted until stationarity is achieved and the null hypothesis is rejected (Katos, 2004). The number of times the time series is differenced determines their order of integration.

\subsubsection{Granger Causality}

According to Gujarati and Porter (2009), Granger causality test explains if it is economic development that causes credit market development or if it is credit market development that causes economic development in Nigeria.

The general formula of the model when the variables are integrated of order zero i.e. when the variables are $\mathrm{I}(0)$ is

$$
\begin{gathered}
B S C / G D P=\alpha_{0}+\alpha_{1} \sum_{1} G D P / G D I_{t-j}+\sum \beta G D P / G D I_{t-j}+\mu_{1 t} \\
G D P / G D I_{t}=\alpha_{0}+\sum_{i=1} \lambda B S C / G D P_{t}+\sum \partial_{j} B S C / G D P_{t-j}+\mu_{2 i}
\end{gathered}
$$

But if any or all the variables are integrated of order one i.e. I(1), the formula becomes

$$
\begin{gathered}
\Delta B S C / G D P_{t}=\lambda_{0}+\sum \lambda_{i} \Delta G D P / G D I_{t-1}+\sum b_{i} \Delta B S C / G D P_{t-i}+V_{t} \\
\Delta G D P / G D I_{t}=\lambda_{0}+\sum \lambda_{i} \Delta B S C / G D P_{t-1}+\sum b_{i} \Delta G D P / G D I_{t-1}+V_{2 t}
\end{gathered}
$$

Where, BSC/GDP and GDP/GDI are variables to be regressed on each other. BSC/GDP represents an indicator of credit market development, while GDP/GDI represents investment productivity. $\mathrm{U}_{1 \mathrm{i}}$ and $\mathrm{U}_{2 \mathrm{i}}$ are mutually uncorrelated while $\alpha, \beta, \delta$ and $\lambda$ are coefficient of lagged variables, $\mathrm{n}$ represents the numbers of lags. The decision rule is that; if past values of a variable GDP/GDI significantly contribute to forecast the value of another variable BSC/GDP, then GDP/GDI is said to Granger cause $\mathrm{BSC} / \mathrm{GDP}$ and vice versa. Specifically, if the estimated coefficients on the lagged BSC/GDP in Eqn. (3.1) are statistically different from zero as a group and a set of estimated coefficients on the lagged GDP/GDI in Eqn. (3.2) is not statistically different from zero, we say that the causality is unidirectional from BSC/GDP to GDP/GDI and vice versa. If the sets of $\mathrm{BSC} / \mathrm{GDP}$ and GDP/GDI coefficients are statistically significantly different from zero in both regressions, the direction of the causality becomes bilateral. Finally, if the sets of BSC/GDP and GDP/GDI coefficients are not statistically significant in either of the regressions, the causality is independent.

\subsubsection{Co-Integration and Error Correction Mechanism}

Co-integration method is adopted to determine the longrun behavior/equilibrium relationship between the dependent variable BSC/GDP and the independent variable GDP/GDI. In the short run there may be disequilibrium, therefore, we can use the error term in the following equation as the "equilibrium error", which can be used to tie the short-run behavior of variables to its long run value. Johnson-Juselius (1990) multivariate co-integration technique will be used. The existence of cointegration among the variables confirms that there is an error correction model that describes the long run relationship of the model. Error correction mechanism is obtained by adding one period lagged variables of the error term to the estimated model i.e,

$$
\begin{aligned}
\Delta B S C / G D P_{t}= & \alpha_{0}+\sum_{i=1}^{k} \beta_{i} \Delta B S C / G D P_{t-i}+\sum_{i=0}^{k} \varphi_{i} \Delta G D P P C_{t-i} \\
& +\sum_{i=0}^{k} \delta_{i} \Delta G D P / G D I_{t-i}+\sum_{i=0}^{k} \gamma_{i} \Delta D R_{t-i} \\
& +\sum_{i=0}^{k} \pi_{i} \Delta T O P_{t-i}+\sum_{i=0}^{k} \lambda_{i} \Delta F D I_{t-i} \\
& +\theta E C M_{t-1}+\varepsilon_{t}
\end{aligned}
$$

Where, $\varepsilon_{\mathrm{t}}$ is the white noise error term.

\subsection{Data Source and Definition of Variables}

\subsubsection{Data Source}

Time series data between 1970 and 2011 from CBN statistical bulletin, World Bank and IMF financial reports were used.

\subsubsection{Definition of Variables}

Investment productivity is measured by ratio of gross domestic product to gross domestic investment (GDP/GDI). Credit market development is measured by the ratio of banking sector credit to real GDP (BSC/GDP) as used in Levine (2002). Trade openness (TOP) is calculated as ratio of total trade to GDP. Interest rate spread (INTRS), measured by the difference between lending rate and deposit rate (Lending Rate - Deposit Rate) is expected to be positively signed as prescribed by Meier (1984) who posits that negative interest rate discourages saving and leads to financial repression in the economy.

\section{Empirical Findings}


The Augmented Dickey-Fuller (ADF) unit root test indicates that BSC/GDP, GDPPC, INTRS, FDI and GDI/GDP are all stationary after first difference; in other words they are integrated of order one; I(1)while TOP is stationary at levels i.e. it is integrated of order zero; $\mathrm{I}(0)$.

Table 1.Augmented Dickey-Fuller unit root test

\begin{tabular}{|c|c|c|c|c|c|}
\hline \multirow{2}{*}{$\frac{\text { VARIABLE }}{\text { GDPPC }}$} & \multicolumn{2}{|c|}{ ADF STATISTIC } & \multicolumn{2}{|c|}{ 5\% CRITICAL } & \multirow{2}{*}{$\frac{\text { INTEGRATION ORDER }}{\mathrm{I}(1)}$} \\
\hline & 0.5086 & -3.5586 & -2.9378 & -2.9399 & \\
\hline $\mathrm{BSC} / \mathrm{GDP}$ & -1.7000 & -5.4056 & -2.9350 & -2.9369 & $\mathrm{I}(1)$ \\
\hline INTRS & -1.7915 & -7.1668 & -2.9378 & -2.9399 & $\mathrm{I}(1)$ \\
\hline TOP & -4.5648 & -7.1784 & -2.9378 & -2.9399 & $\mathrm{I}(0)$ \\
\hline FDI & -0.3538 & -5.3077 & -2.9378 & -2.9399 & $\mathrm{I}(1)$ \\
\hline GDP/GDI & -1.8258 & -4.2086 & -2.9369 & -2.9369 & $\mathrm{I}(1)$ \\
\hline
\end{tabular}

Note:The variables are expressed in their natural logarithms.

Table 2. Credit Market Development Model

\begin{tabular}{|c|c|c|c|c|}
\hline VARIABLE & COEFFICIENT & STD. ERROR & T-STATISTIC & PROB. \\
\hline $\mathrm{C}$ & -0.032641 & 0.060190 & -0.542293 & 0.5919 \\
\hline D(LOG(BSC_GDP(-1))) & 0.366783 & 0.117866 & 3.111879 & 0.0043 \\
\hline D(LOG(GDP_GDI(-1))) & -0.226166 & 0.071411 & -3.167108 & 0.0037 \\
\hline D(LOG(GDPPC(-1))) & -2.554202 & 1.123750 & -2.272927 & 0.0309 \\
\hline D(LOG(INTRS(-1))) & -0.051050 & 0.113354 & -0.450362 & 0.6559 \\
\hline $\mathrm{D}((\mathrm{TOP}(-1)))$ & -0.622261 & 0.088023 & -7.069316 & 0.0000 \\
\hline $\mathrm{D}((\operatorname{FDI}(-1)))$ & $4.36 \mathrm{E}-06$ & $1.23 \mathrm{E}-06$ & 3.534044 & 0.0014 \\
\hline $\mathrm{D}((\operatorname{FDI}(-2)))$ & $-5.74 \mathrm{E}-06$ & $1.98 \mathrm{E}-06$ & -2.897437 & 0.0072 \\
\hline $\mathrm{D}((\operatorname{FDI}(-3)))$ & 4.87E-06 & $1.62 \mathrm{E}-06$ & 3.012216 & 0.0055 \\
\hline $\operatorname{ECM}(-1)$ & -0.028721 & 0.007136 & -4.024649 & 0.0004 \\
\hline R-squared & 0.740455 & \multicolumn{2}{|c|}{ Mean dependent var } & 0.033291 \\
\hline Adjusted R-squared & 0.657029 & \multicolumn{2}{|c|}{ S.D. dependent var } & 0.538424 \\
\hline S.E. of regression & 0.315321 & \multicolumn{2}{|c|}{ Akaike info criterion } & 0.750482 \\
\hline Sum squared resid & 2.783963 & \multicolumn{2}{|c|}{ Schwarz criterion } & 1.181426 \\
\hline Log likelihood & -4.259162 & \multicolumn{2}{|c|}{ Hannan-Quinn criter. } & 0.903809 \\
\hline F-statistic & 8.875658 & \multicolumn{2}{|c|}{ Durbin-Watson stat } & 2.087307 \\
\hline Prob(F-statistic) & 0.000004 & & & \\
\hline
\end{tabular}

Dependent Variable: D(LOG(BSC_GDP))

The co-integration result (not shown here due to space constraint) for the credit market development (BSC/GDP) indicates six co-integrating equations at 5 percent level of significance in both the Trace statistic and Max-Eigen statistic. This implies the existence of long run relationship between BSC/GDP, GDPPC, INTRS, TOP and FDI.

An evaluation of the result in Table 2 suggests that the model is a good fit to the long run relationship between banking sector credit development and investment productivity. About 74 percent of the changes in banking sector credit development are explained by changes in investment productivity and other control variables as measured by R2, the coefficient of determination. The $\mathrm{t}$ statistics show that individual variables except INTRS are statistically significant at 1 percent or 5 percent levels of significance. This shows that if economic decisions are taken on these variables, they will cause changes in the dependent variable (BSC/GDP). The F-statistic of 8.87 is statistically significant at 1 percent and confirms that the model is a good fit that is reliable for formulating economic policies. By the rule of the thumb the Durbin-Watson statistic of 2.0 signifies the absence of serial autocorrelation in the model, indicating that the value which the residuals assumed in one period is independent from the value which it assumed in any previous period. The error correction term (ECM) is fractional, negative and statistically significant. Thus, long run relationship exists between the dependent variable and the independent variables. The ECM also shows a sluggish speed of adjustment as only about 2.9 percent short term error in the model can be corrected in the long run at a given period. The CUSUM test as shown in fig. 2 confirms the stability of the parameters as they are within $5 \%$ confidence limits. Also the CUSUM of square test, shown in fig 3 is used to test for 
the stability of the residuals of the model. The result shows that within the period of the study, the residuals of the model were stable as shown by the movement of the trend within the bounds at \pm 5 percent levels of significance.

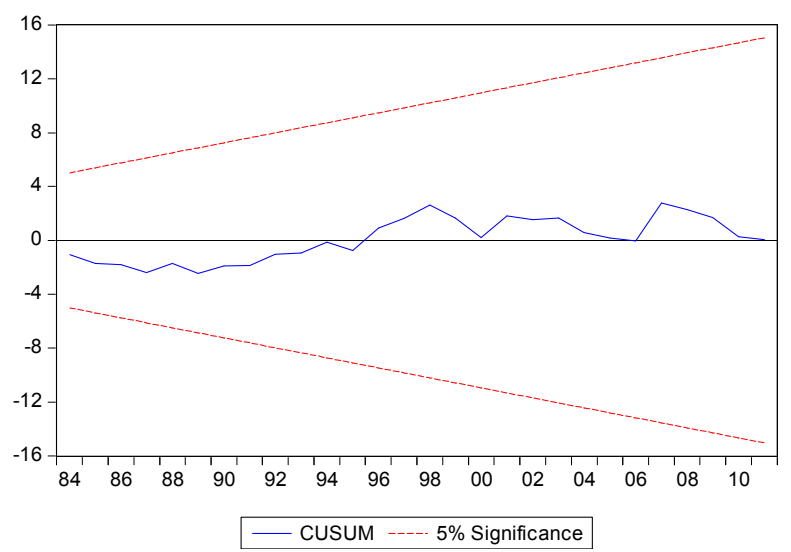

Fig2. Stability Test for Parameters

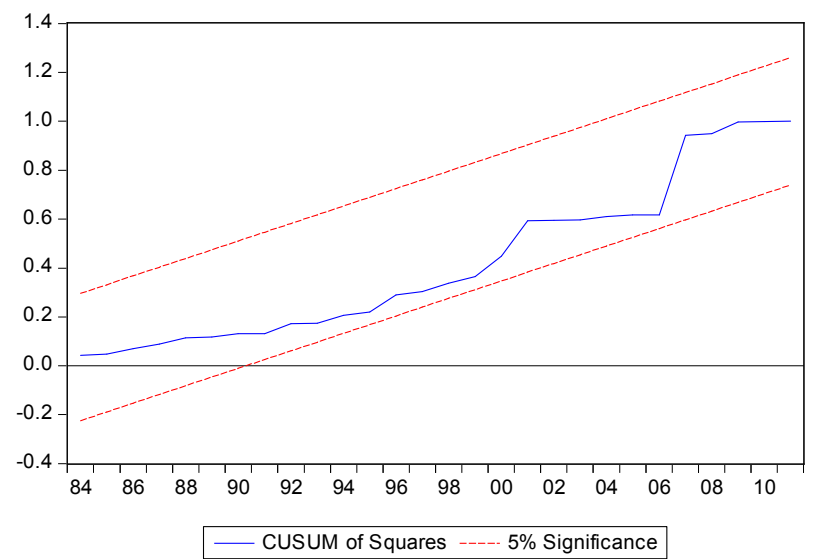

Fig 3.Stability Test for Residuals

From the result shown in the Table 2, interest rate spread; difference between lending and deposit rates is properly signed but not statistically significant. The higher the lending rate is compared to the deposit rate the higher will be the interest rate spread and the higher the interest rate spread the less the borrowing and hence the less developed will be the bank credit market. This captures the concept of effective utilization of credits in line with opportunity cost principles. However, when the lending rate far exceeds the deposit rate it discourages both savings and investment. The numerical interpretation of the coefficient indicates that a 100 percent increase in interest rate spread brings about 5 percent decrease in banking sector development. Trade openness is found to be statistically significant but negatively signed contrary to apriori expectation. Thus a 100 percent increase in trade openness will result in 62 percent decrease in banking sector credit development suggesting that the more we open our boarders to trading, the less will credits be available in the banking sector. This uncomfortable result may be providing us with evidence as to the channel of capital flight from the country. It is a known fact that; through oil and other trades with multinationals huge capital is flown out abroad without reciprocal returns. Hence it is not surprising that we have such an adverse result with trade openness. The result on FDI is statistically significant but mixed in signs within three time periods. The positive sign in the first period captures the burst in investible funds that usually will pass through the banks. In the second period, the funds are invested and undergoing a gestation period and so do not feedback to the banks hence the negative sign but in the third period they begin to yield returns and contribute positively to increase in the development of bank credits. Their contributions however are meager in size. An understanding of the above results and explanations is necessary for a thoughtful follow through of the explanations of the relationship and effect of investment productivity and per capita income on banking sector credit development. Apriori expectation on investment productivity (GDP/GDI) is positive but it turned out to be negative but statistically significant. On the surface, this implies that 100 percent increase in investment productivity will bring about 23 percent decrease in banking sector credit development. However, it is important to consider that the ratio GDP/GDI increases if GDI (Gross Domestic Investment) is decreasing. A decrease in GDI in agreement with the Supply-Leading hypothesis will decrease and slow down growth. The consequence of this among others is low savings and therefore less credit to the banks. This result is consistent with the Nigerian scenario. As pointed out earlier, investment in Nigeria is indeed low compared to those of Indonesia and South Africa. It is therefore a pointer to our macroeconomic managers that appropriate policy is required to reverse the trend such that a reasonable percentage of our output is invested in the productive sectors of the economy. According to the feedback theory, GDP per capita; GDPPC feeds on investment and therefore responds in similarity to GDI. It is therefore not surprising that we have a negative effect of GDPPC on banking sector credit development. This further highlights the insensitivity of Nigerians to credit market investment as a result of low deposit rate.

\section{Conclusion}

This study examined the relationship existing between bank sector credit market development and investment productivity in Nigeria from 1970-2011 using error correction mechanism. We observed that the improvement in the banking sector reforms ranging from structural adjustment programme (SAP) to the present consolidation era has not been translated to credit market development. This is attributed to inefficient utilization of credit market funds which results in low level of per capita income, low level of investment and ultimately poorly developed banking credit market in Nigeria. Therefore, policies to correct this anomaly should focus on the management of lending and deposit rates so that the spread; difference between them is nottoo wide. Based on the findings of the study, the 
following policy implications can be drawn: increase in deposit rate will encourage savings, promote credit market development and increase investment. Similarly; a reduction in lending rate will encourage borrowing for capital project financing that will lead to increased investment productivity, increased output, better use of the bank credit market and hence a better developed credit market. Through this, development in the credit market can contribute significantly to economic development via investment productivity. There is the need to increase per capita income through encouraged participation in credit market investment. Thus returns on investment in the credit market should be improved. At present people prefer to spend their money on consumption goods because of the discouraging low deposit rate in the banks. Improved deposit rate will definitely improve investment productivity and economic development through the multiplier process. Foreign direct investment has been found to encourage investment productivity; policy should be geared towards attracting more FDI in Nigeria.

\section{References}

[1] Acemoglu, D. (2004). Institutions as the fundamental cause of long- run growth. NBER Working Paper, 10481, 11-17. Retrieved from http://www.nber.org/paper/w10481.pdf

[2] Athanasios, V. \&Antonios, A. (2010). The effect of stock and credit market development on economic growth: An empirical analysis for Italy. International Research Journal of Finance and Economic, 1540-2887.Retrieved from http://www.eurojournal.com/finance.html

[3] Atje, R. \&Jovanovic, B. (1993). Stock markets and development. European Economic Review, 37,634- 640.

[4] Bencivenga, V. \& Smith, B. (1996). Financial intermediation and endogenous growth. The Review of Economic Studies, 58, 195-209.

[5] Caporale, G., Howells, P. \&Soliman, A. (2005). Endogenous growth models and stock market development: Evidence from four countries. Review of Development Economics, 9, 166-176

[6] David, T. K. (2003). Nigerian financial sector assessment. Report for USAIN/ Nigeria; Economic Growth Strategy, GS-23f-97584-001.

[7] Demetriades, O. P. \& Hussein, A. K. (1996). Does financial development cause economic growth? Time series evidence from 16 countries. Journal of Development Economics, 51, $387-411$.
[8] Greenwood, J. \&Jovanovic, B. (1990). Financial development, growth, and the distribution of income. Journal of Political Economy, 5(1), 1076-1107.

[9] Gross, M. D. (2001). Financial intermediation: a contributing factor to economic growth and employment. ILO Publication,92-2-112895-4. Retrieved from www.ilo.org/employment/Whatwedo/Publications/.../index.ht $m$

[10] Kasekende, L. (2008). Developing a second banking system. Paper presented at the International Monetary Fund Seminar, Tunisia.

[11] Kyle, A. (1984). Market structure, Information, future markets and price formation. Journal of Economic Dynamics and Controls, 20(1), 51-79.

[12] Levine, R. (1991). Stock market, growth, and tax policy. Journal of Finance, 46(4), 1445-1465

[13] Lucas, R. (1988). On the mechanics of economic development". Journal of Monetary Economics, 22(1), 2-42.

[14] Luintel, K. \&Mosahid, K. (1999). A quantitative reassessment of the finance-growth nexus: Evidence from a multivariate VAR. Journal of Development Economics, 60, 381-405.

[15] Mishkin, F. S. (2007). The Economics of Money and Financial Markets $\left(10^{\text {th }}\right.$ ed.). India: Prentice Hall

[16] Mishra, P. K., Das, K. B. \& Pradhan, B. B. (2009). Economic growth: Financial innovation perspective. BIFT's Journal of International Management and Research, 1(1), 69-73.

[17] Nzue, F. (2006). Stock market development and economic growth: Evidence from Cote D'Ivore. Journal of Africa Development Review, 18(1), 123-145.

[18] Oluitan, R. (2009). Bank credit and economic growth: the Nigerian experience. Retrieved from http://www.csae.ox.ac.uk/conference/2009EDRA/papers/094

[19] Osei, V. (2005). Does the stock market matter in Ghana? A granger-causality analysis. Bank of Ghana working Paper,5(13), 5-10.

[20] Saci, K., Giorgioni, G. and Holden, K. (2009). Does financial development affect growth? International Journal of Accounting, 44(1), 79-102.

[21] Schumpeter, J. A. (1911). The theory of economic development. Cambridge, CA: Harvard University Press.

[22] Vazakidis, A. \&Adamopouslos, A. (2009). Credit market development and growth. American Journal of Economics and Business Administration, 1(1), 34-40. 